\title{
Zombie business strategies: The case of Ukraine
}

\author{
Pedro Pardal, Ihor Hurnyak, Aleksandra Kordonska
}

\begin{abstract}
A B S T R A C T
Objective: The objective of the article is to study zombie business strategies in Ukrainian practice and present the influence of traditional and manipulative tools on business activity in conditions of weak institutional environment. Research Design \& Methods: We apply linear and logistic regression to estimate the impact of traditional and manipulative tools on the investment possibilities by using data from a sample of small enterprises in Ukraine in 2015-2018. The results of the logistic regression were used to present Nash equilibrium in the payoff matrix to explain the coexistence of traditional and manipulative tools in doing business through the prism of interests of the society as a whole.
\end{abstract}

Findings: Evidence revealed that the Ukrainian market creates a special type of zombie business resulting from ineffective government policy and unfavourable institutional environment. Moreover, in conditions of weak stock market, this practice could be used not only in Ukraine but also expanded to countries with similar problems. The main problem is the fact that - in the case of searching for the desired level of profitability - Nash equilibrium on the Ukrainian market combines manipulative and traditional tools.

Implications \& Recommendations: Considering the business environment that characterized by unprofitability, the equilibrium between adherents of traditional and manipulative mechanisms is reached on the market where the latter prevail. This situation becomes a serious problem for reforms, as fight against manipulative practices by weak market institutions happens almost outside real business. The problem explains why the government and small business practically coexist by interacting only partially without opposition and counteraction. In the case of searching for the desired level of profitability (if the market is in equilibrium), a reformation or transformation of the system will be accompanied by obvious resistance. Our study informs about the risks and economic effects of zombie firms. We recommend the creation of a favourable institutional environment through effective public policies.

Contribution \& Value Added: We emphasize the undeniable fact that small business is officially completely unprofitable in Ukraine. The article helps to understand the essence of zombie business. It is one of the first attempts to develop a comprehensive analysis of zombie business by a wide range of manipulative tools of financial statements that apply game theory models.

$\begin{array}{ll}\text { Article type: } & \text { research article } \\ \text { Keywords: } & \text { zombie business; strategy; institutions; Nash equilibrium; Ukraine } \\ \text { JEL codes: } & \text { D22, D25, M21, M42, L26 }\end{array}$

Received: 28 March $2020 \quad$ Revised: 18 September $2020 \quad$ Accepted: 4 November 2020

\section{Suggested citation:}

Pardal, P., Hurnyak, I., \& Kordonska, A. (2021). Zombie business strategies: the case of Ukraine. Entrepreneurial Business and Economics Review, 9(1), 47-59. https://doi.org/10.15678/EBER.2021.090103

\section{INTRODUCTION}

The prevalence of zombie firms has ratcheted up since the late 1980 s. According to the Bank of International Settlements, a zombie firm is a listed firm with ten or more years of existence, in which the ratio of earnings before interest and taxes (EBIT) relative to interest expense is lower than one (Lacalle, 2017). In essence, as shown by Lacalle (2017), a zombie firm is a company that merely survives due to the constant refinancing of its debt and - despite re-structuring and low rates - remains unable to cover its interest expense with operating profits. Caballero et al. (2008) coined the term in their anal- 
ysis of the Japanese 'lost decade' of the 1990s. They define a zombie firm as a company that persistently has problems with financial obligations (Caballero et al., 2008) and shows inefficiency (Ahearne $\&$ Shinada, 2005). This appears to be linked to reduced financial pressure, reflecting in part the effects of lower interest rates (Banerjee \& Hofmann, 2018).

The term 'zombie' is also applied to banks having the influence on business. The problem of zombie banks in the modern economy results from the strong growth of nonperforming loans - a unique indicator of financial health in the banking system. According to Stephen Bush (2018), the term 'zombie bank' appeared more than 25 years ago when the savings and loan crisis in the United States of America resulted in hundreds of financial institutions having liabilities in excess to their assets. Japan is the first well documented case of zombie banking in a developed economy. Moreover, the banking crisis in Europe shares many similarities to the situation in Japan (Acharya \& Steffen, 2014; Henselmann et al., 2016; Kanaya \& Woo, 2000; Kawai, 2005; Mora, 2017; Nakaso, 2001; Radivojevic \& Jovovic, 2017; Schnabl, 2013; Schoenmaker \& Peek, 2014; Willam, 2015). Meanwhile, during the crisis period, the sustainability of banks and business were negatively affected by leverage (Berger \& Bouwman, 2013; Molina, 2005; Olaniyi et al., 2015). Novita, Tjahjadi, and Irwanto (2018) show how leverage affects firm's fragility and financial soundness during the financial and industry crises based on the example of Indonesian non-financial firms in the period from 2007 to 2016. Their evidence reveals that leverage has a statistically significant correlation with a firm's fragility and affects the firm's financial soundness during an economic crisis. Thus, the higher the debt of a company, the lower its financial soundness during the crisis (Alfaro et al., 2017; Männasoo et al., 2017). However, Urionabarrenetxea et al. (2018) state that the zombie category has no correlation with leverage because the level of leverage is uniformly distributed across the firm.

Using Google Books Ngram Viewer (Figure 1), we may observe the increase of investigations related to zombie business in 1980-1990 and at the beginning of the twenty-first century, while the studies related to zombie banks became popular since 1994. The data presented in Figure 1 show that the problem of zombie businesses is relevant but still neglected by scholars compared to the frequent appearance of the term 'zombie banks.' Therefore, we want to study the phenomenon of zombie businesses in Ukraine and present the influence of a selected strategy (of using traditional / manipulative tools) on business activity in conditions of weak institutional environment.

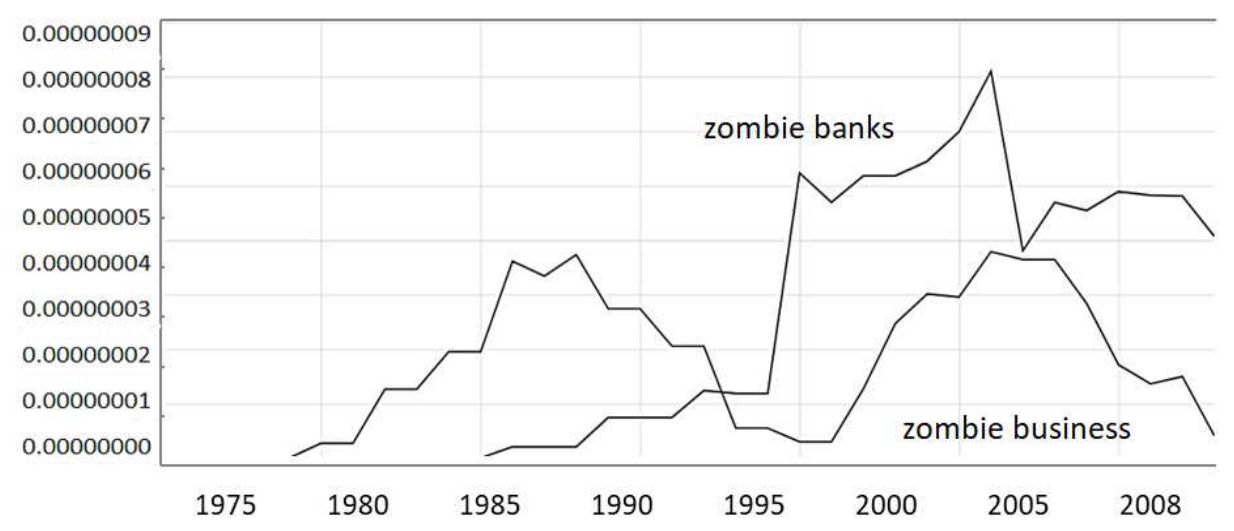

Figure 1. Search frequencies (\%) for the term 'zombie business' and 'zombie banks' in sources printed between 1975 and 2008 Source: adapted from Google Books Ngram Viewer.

The rest of the paper is structured as follows. In the first part of the article (Literature Review), we present a theoretical framework to the research topic, along with advances and contributions of existing literature. In the second part (Material and Methods), we discuss the methodological basis for the research. The next part (Results and Discussion) contains a brief analysis of the Ukrainian business environment (in order to show the relevance of the study in this particular economy) and a test of proposed hypotheses; firstly, by using a linear regression model and, secondly, by a logistic regression approach. The results of logistic regression became the basis for Nash equilibrium in the payoff matrix, 
which explains the influence of traditional and manipulative tools in doing business through the prism of the whole society's interests. The last part presents conclusions.

\section{LITERATURE REVIEW}

Banerjee and Hofmann (2018, p. 68) focus on addressing the following questions:

1. 'Are the increases in the incidence of zombie firms just episodic, linked to the major financial disruptions, or do they reflect a more general trend? 'Scientists found that 'share of zombie companies has trended up over time through upward shifts in the wake of economic downturns that are not fully reversed in subsequent recoveries.'

2. What are the causes of the rise of zombie firms? 'The results of the article suggest that lower rates tend to push up zombie shares, even after accounting the impact of other factors.'

3. What are the economic consequences of the rise of zombie companies? The higher share of zombie companies could be weighing on aggregate productivity. Moreover, the survival of zombie firms may crowd out investment and employment at healthy firms.'

Their findings confirm these effects for 14 advanced economies since the late 1980 s.

McGowan et al. (2017) find that 'within-industries over the period 2003-2013, a higher share of industry capital sunk in zombie firms is associated with lower investment and employment growth of the typical non-zombie firm and less productivity-enhancing capital reallocation.'

Caballero et al. (2008) examine zombie lending and depressed restructuring in Japan. The researchers note that 'congestion created by the zombies reduces the profits for healthy firms, which discourages their entry and investment' (Caballero et al., 2008). They prove that zombie-dominated industries exhibit more depressed job creation and destruction, along with lower productivity, as the increase in zombies depressed the investment and employment growth of non-zombies and widened the productivity gap between zombies and non-zombies. By keeping these unprofitable borrowers alive, the banks allowed them to distort competition throughout the rest of the economy (Caballero, Hoshi, \& Kashyap, 2008).

Storz et al. (2017) examine the effect of stressed bank on the deleveraging process of small and medium-sized enterprises (SME), focusing on zombie firms in the euro area. Based on information concerning 400000 SME over 2010-2014, they find significant association between the increase in the standard deviation of bank stress and the increase of firm leverage in zombie firms from the euro area periphery countries (Greece, Ireland, Portugal, Spain, and Slovenia). Findings also suggest that the deleveraging process of non-financial corporations could be hindered by bank weakness, since these banks may have an incentive to evergreen loan to zombie firms so as to avoid the recognition of impairments and gamble with future economic recovery. As discussed in the previous studies, this behaviour resulted in the misallocation of credit to low productive firms.

Barros et al. (2017) study the existence and economic effect of zombie firms in the non-tradable sectors of Construction and Services in Portugal in 2008-2015. They find that higher amounts of resources stuck in zombie firms are, in average, negatively related to investment and job creation by healthy firms. They suggest that the presence of zombie firms slowed down economic recovery by distorting the application of resources by healthy firms.

Goto and Wilbur (2019) focused their study on Japanese firms from the so-called lost decades' period. Evidence suggests that zombies existed to a significant degree in the past and at a comparably higher level than large-sized zombie firms estimated in previous studies. This research also examines corporate characteristics of zombie small and medium-sized enterprises (SMEs) and offers evidence that several firms managed to escape from zombie status through recovery or exit. The probability of exit is higher for zombies that are SMEs.

Schivardi et al. (2017) define zombie companies by two measures of profitability: return on assets (ROA) and a measure of default risk, that is, leverage; according to the authors, the latter is a total financial debt over total assets. 'Then, if the ROA is below prime rate while the level of leverage is greater than a threshold value, the firm is classified as a zombie. Meanwhile, Fukuda and Nakamura 
(2010) indicate that the 'evergreen lending criterion.' Under this criterion, firms which are 'unprofitable and highly leveraged with increasing external borrowings' are defined as zombies.

The majority of discussed measures combine indicators of low profitability and a high default risk. This approach enables a focus on the dynamic factors in the case of low value of a company's equity and obligations of the company, including different types of debt and retained earnings. In our opinion, it seems appropriate to develop the approach by using a much more integral indicator of retained earnings instead of EBIT because it contains data from previous years and can provide a more informative representation of a business.

Considering Ukrainian zombie businesses that function in the unfavourable environment of market institutions, we would like to propose the following hypotheses:

H1: The problem concerning banks reluctant to make loans to small businesses in Ukraine is solved by the use and accumulation of other types of liabilities (advance payments, salaries, insurance, debt to supplier, etc.).

H2: The firm uses manipulative tools in operational activities with the aim to maintain a stable level of profitability or its positive dynamics (in the case of unfavourable institutional environment for business).

H3: In conditions of ineffective market institutions and 'permissible' negative fluctuations in profitability, the use of business strategy based on manipulative tools does not serve to support businesses but distorts the real performance of businesses.

\section{RESEARCH METHODOLOGY}

The methodological basis for this study is both economic and statistical methods. First of all, we will make a brief analysis of the business environment in Ukraine based on World Bank data in order to prove the relevance of the solution and to explain what needs to be done to ensure a favourable business environment. Then, we will analyse the performance of Ukrainian business in terms of profitability, which will allow us to assess the efficiency of investments and the rationality of their use.

In the next part (Results and Discussion), we will test the hypotheses with several methods. On the one hand, we could identify opportunities of the accumulation of additional debt on balance sheet that arose from manipulation practices with retained earnings. However, such an analysis does not make sense in Ukraine because there are different non-consistent approaches in the preparation of separate financial statements. Therefore, we believe that a linear regression would be sufficient for our analysis. In some cases, it will be appropriate to apply a logistic regression model that allows us to reveal the percentage of correct predictions.

In order to achieve our research objectives, traditional and manipulative tools in doing business will be studied to reveal the essence of zombie business strategies in Ukraine. Based on accounting theory, we consider as traditional instruments the differentiation of inventory costing methods, the method of amortization/depreciation, financial/operating lease, the reduction of expenses, etc. On the other hand, we consider accumulated debt from the suppliers of goods and services, the state, and the employees, along with advance payments as manipulative instruments.

Therefore, we would like to test the impact of particular types of liabilities and costs on retained earnings - based on information from balance sheets and financial statements - on the selected sample of Ukrainian small enterprises in 2015-2018 (a total of 123 annual data lines). Data for the research was taken from the stock market infrastructure development agency of Ukraine. For this purpose, we will use a multiple linear regression model and the following abbreviations for the variables: current portion of long-term debt - LTD, current liabilities for goods, work and services - CL_GWS, current liabilities for insurance - CL_INS, current liabilities for labour costs - CL_LC, current liabilities for customer prepayments $-\mathrm{CL}_{-}$ADV. The models also contain such variables as administration costs (ADM_COSTS), sales costs (SALES_COSTS), financial costs (FIN_COSTS), indebtedness to the budget (IND_B), and income tax liability (ITL). 
Then, assuming nonlinearity on technology markets and the improbable presentation of real financial situation in financial statements, we will use logistic regression for testing the hypotheses. The results of our investigation on the basis of linear and logistic regression approach will confirm or reject the possibility of manipulation with long-term debt and current liabilities in Ukrainian business practice.

On the other hand, in light of the overwhelming level of the informal economy in Ukraine and manipulative practices with formal and informal cash flows, we should also employ game theory models rather than make direct calculations. Such an approach was also used by Bilotkach (2006) who examines the problem of tax evasion by enterprises through underreporting activity based on equilibrium of the game between a businessman and an imperfectly monitored supervising official, in which the businessman can hide a part of his profit and offer a bribe to the official. Hence, for testing the third hypothesis, we present a payoff matrix based on the results obtained from the logistic regressions (for this purpose, we use overall percentage of correct predictions), which allows us to show the influence of traditional and manipulative tools in doing business. On the other hand, we also use payoff matrix to present the choice of a strategy by zombie firms in the case of unprofitability. The results of regression studies and payoff matrix used for reflecting a business environment present the originality of the research.

Consequently, we can state that the majority of studies on the topic mainly focuses on the loss of investment and hiring of workers by non-zombie firms or on smaller labour productivity of zombie firms. Meanwhile, we pay attention to the mechanisms and conditions related to the functioning of zombie businesses in conditions of weak market institutions on the example of Ukraine. In fact, the mentioned studies indicate the impact and consequences of the zombie business phenomenon but do not show its interaction with market institutions.

\section{RESULTS AND DISCUSSION}

\section{Ease of doing business and profitability of enterprises in Ukraine}

In Doing Business 2019, Ukraine ranked 71th among 190 countries, rising five positions compared to its 76th place rank in 2018, eighteen positions compared to its 89th place in 2017, and 66 positions compared to its 137th place in 2013. Based on the rankings presented in Table 1, we observed the changes in its positions among world economies in the last six years for 10 indicators of the 'ease of doing business'. A comparison of the economy's indicators today with those in the previous years may show where substantial bottlenecks persist - and where they are diminishing.

Table 1. The ease of doing business ranking in Ukraine, 2013-2019

\begin{tabular}{|l|c|c|c|c|c|c|c|c|}
\hline \multicolumn{1}{|c|}{ Year / ranking } & $\mathbf{2 0 1 3}$ & $\mathbf{2 0 1 4}$ & $\mathbf{2 0 1 5}$ & $\mathbf{2 0 1 6}$ & $\mathbf{2 0 1 7}$ & $\mathbf{2 0 1 8}$ & $\mathbf{2 0 1 9}$ & $\begin{array}{c}\text { Change in ranking } \\
\text { during 2013-2019 }\end{array}$ \\
\hline Overall ranking & 137 & 112 & 96 & 83 & 89 & 76 & 71 & +66 \\
\hline Starting a business & 50 & 47 & 76 & 24 & 20 & 52 & 61 & -11 \\
\hline Dealing with construction permits & 183 & 41 & 70 & 137 & 140 & 35 & 20 & +163 \\
\hline Getting electricity & 166 & 172 & 185 & 140 & 130 & 128 & 128 & +38 \\
\hline Registering property & 149 & 97 & 59 & 62 & 63 & 64 & 61 & +88 \\
\hline Getting credit & 23 & 13 & 17 & 19 & 20 & 29 & 37 & -14 \\
\hline Protecting minority investors & 117 & 128 & 109 & 101 & 70 & 81 & 45 & +72 \\
\hline Paying taxes & 165 & 164 & 108 & 83 & 84 & 43 & 65 & +100 \\
\hline Trading across borders & 145 & 148 & 154 & 110 & 115 & 119 & 74 & +71 \\
\hline Enforcing contracts & 42 & 45 & 43 & 93 & 81 & 82 & 63 & -21 \\
\hline Resolving insolvency & 157 & 162 & 142 & 148 & 150 & 149 & 146 & +11 \\
\hline
\end{tabular}

Source: own elaboration of the World Bank Data Catalog, Doing Business.

In assessing progress based on ten criteria in the past six years, Ukraine showed a good performance in dealing with construction permits $(+163)$, making it easier by reducing fees; paying taxes $(+100)$ by reducing the rate for the single social contribution tax; registering property $(+88)$; protecting 
minority investors $(+72)$ by requiring detailed immediate public disclosure of related-party transactions; and in trading across borders (+71). Meanwhile, we observed a decrease in enforcing contracts (-21); getting credit (-14); starting a business (-11). Keeping in mind these indicators, we considered whether the institutional changes show the real state of matters or maybe just a desirable one? Our research was to answer this question. Meanwhile, we assumed that institutional environment in Ukraine is, in fact, weak and turbulent, without any effective institutional framework for productive entrepreneurship. Institutions - the framework of the competitiveness in the developed countries are not sufficiently developed in Ukraine. This conclusions surfaces from studies by Smallbone et al. (2010), Tiffin (2006), and Kyselova (2015). Then, Bilan et al. (2019) prove the significant influence of shadow economy on the demand level in the Ukrainian investment market. The level of institutional quality in Central and East European countries and its impact on investment attractiveness is considered by Dorożyński et al. (2020).

According to data from the State Statistic Service of Ukraine (Table 2), by taking into account the whole business activity, we observed that profitability ratio of small enterprises is negative in 20102018. Low profitability primarily resulted from excessive operating costs, inadequate revenue, or in most cases, a combination of both. The highest level of profitability appeared in some sectors of Ukraine's economy, such as agriculture, forestry, transport and communications, and education. Meanwhile, the service sector and industry generally remained unprofitable.

Table 2. Profitability ratio of large, medium-sized, small and micro enterprises in Ukraine during 2010-2018

\begin{tabular}{|c|c|c|c|c|c|c|c|c|c|c|}
\hline \multirow{3}{*}{ Year } & \multicolumn{5}{|c|}{ Profitability ratio (operating activities), \% } & \multicolumn{5}{|c|}{$\begin{array}{c}\text { Profitability ratio } \\
\text { of the whole business activity, } \%\end{array}$} \\
\hline & \multirow[b]{2}{*}{ overall } & \multicolumn{4}{|c|}{ Enterprises by categories } & \multirow[b]{2}{*}{ overall } & \multicolumn{4}{|c|}{ enterprises by categories } \\
\hline & & large & $\begin{array}{l}\text { medium- } \\
\text { sized }\end{array}$ & small & micro & & large & $\begin{array}{l}\text { medium- } \\
\text { sized }\end{array}$ & small & micro \\
\hline 2010 & 4.0 & 3.9 & 5.0 & 1.8 & -3.5 & 0.5 & 0.2 & 2.3 & -5.7 & -13.9 \\
\hline 2011 & 5.9 & 6.2 & 6.0 & 4.2 & 0.8 & 1.8 & 3.3 & 1.2 & -2.5 & -8.0 \\
\hline 2012 & 5.0 & 5.2 & 5.0 & 4.1 & -0.1 & 1.0 & 0.9 & 2.2 & -3.3 & -10.2 \\
\hline 2013 & 3.9 & 5.0 & 3.2 & 2.2 & -2.3 & -0.7 & 0.6 & -0.1 & -6.2 & -16.1 \\
\hline 2014 & -4.1 & 0.7 & -3.6 & -17.9 & -30.1 & -14.2 & -11.1 & -12.5 & -26.5 & -40.2 \\
\hline 2015 & 1.0 & 4.0 & 0.0 & -4.2 & -8.2 & -7.3 & -7.0 & -5.0 & -13.6 & -20.4 \\
\hline 2016 & 7.4 & 8.8 & 6.9 & 5.2 & -0.4 & 0.6 & 2.4 & 0.7 & -3.6 & -11.7 \\
\hline 2017 & 8.8 & 11.2 & 7.3 & 6.5 & 2.4 & 3.0 & 5.2 & 3.1 & -2.0 & -8.0 \\
\hline 2018 & 8.1 & 9.1 & 7.0 & 8.3 & 4.7 & 4.5 & 5.2 & 4.6 & 2.7 & -1.8 \\
\hline
\end{tabular}

Source: own elaboration of the State Statistics Service of Ukraine.

The phenomenon of Ukrainian business lies in the very nature of institutional environment: the majority of small firms has no reason to hide'profits by using accounting methods. They work only partially in the official economy while having a lot of 'cash assets'outside of it. The long-term negative financial results do not affect them because the state does not use mechanisms to counteract such practices. It seemed appropriate to state that such firms do not pay income tax but look for additional financial resources by increasing the level of debt. In this case, it was unreasonable to consider the poorly functioning banking system, the bond market (focusing only on government bonds with extremely high yields), or the undeveloped stock market as significant factors that affect business in Ukraine. Consequently, such a special nature of business in Ukraine confirmed the relevance of our study of zombie businesses.

\section{Simplified linear approach}

To check our hypotheses, we tested the impact of particular types of liabilities on retained earnings based on annual data of financial statements for selected small enterprises (Table 3). Considering the specifics of the balance sheet data, which is not cumulative but fixed at a specific date, there was no sense to use the gain up to the previous year or to calculate the relative change of the indicator. 
According to the results, all determined factors could have become tools used in manipulative practices. We noted that the determinant 'retained earnings' also included information concerning the inputs from previous periods that could significantly affect company leverage and other indicators. Considering the influence of the same factors for the 'net income', all independent variables were insignificant except for CL_ADV (Beta coefficient $=-0.5, p-$ value $=0.000$ ). It confirmed that manipulative practices can be 'effective' by using such resources for several years.

Table 3. The influence of current liabilities on the retained earnings; based on a selected sample (a total of 123 data lines) of Ukrainian small enterprises in 2015-2018

\begin{tabular}{|c|c|c|c|c|c|}
\hline variables & LTD & CL_GWS & CL_INS & CL_LC & CL_ADV \\
\hline Beta & 0.192 & -0.152 & 0.337 & -0.698 & -0.305 \\
\hline$p$-value & $0.001^{* * *}$ & $0.135^{*}$ & $0.000^{* * *}$ & $0.000^{* * *}$ & $0.000^{* * *}$ \\
\hline
\end{tabular}

Notes: LTD - current portion of long-term debt; CL_GWS - current liabilities for goods, work and services; $C L$ INS - current liabilities for insurance; CL_LC - current liabilities for labour costs; CL_ADV - current liabilities for customer prepayments. Adjusted R-square value (a descriptive power of the regression model) $=0.738$. F-statistic (statistical significance of the model) $=52.288 ;{ }^{*}-$ significance at $10 \%$ level, $*^{*}$ - significance at $5 \%$ level, $* * *$ - significance at $1 \%$ level. Variance Inflation Factor does not exceed the level 'moderately correlated.' Source: own study.

Therefore, debt manipulation weakly correlated with the current level of profitability (here we draw your attention to the third hypothesis). Hence, the manipulative tools can influence business in the medium or long term. Such a situation does not pose a problem for Ukrainian firms because bankruptcy of a firm that faces several lawsuits allows it to change its form of ownership, participate in tenders and win them, conduct current business, and even receive credit. Let us note that equity was used in a wide range of financial ratios, while profitability was unlikely to be interesting as the simple result of accountant skills. If the stock market is weak, there is no risk of bankruptcy due to the prolonged official loss and widely used manipulations with costs. Then, we also tried to use the 'revenue' as dependent variable. In such a study, all independent variables were to be significant.

If we expanded the model by some traditional tools such as depreciation and operational losses by taking into account all possible payments relative or not directly relative to the type of production before the tax profit calculation - the result of the estimation significantly differs from the previous one. The adjusted R-square crossed the mark 0.975 , but the most influencing variables of the previous model lost their significance: $\mathrm{CL}$ INS and $\mathrm{CL}$ ADV are still significant with $p-$ value $=0.05$, but essentially weaker. A deeper expansion of these models was not needed for our analysis because we focused on studying the direction of using operational flows and different strategies but not the comparative influence of the particular factors.

\section{Delta approach}

In general, the linear regression approach required aggregated variables. Annual balance sheet data introduced information at the beginning and at the end of the year. Then, they did not fully reflect dynamics during the year. Thus, in the next step we tested the influence of particular determinants on 'retained earnings' by using a delta approach aimed at the application of average values in the analysis. The difference between the variables at the beginning and at the end of a certain period was conveyed by the following formula:

where:

$$
\Delta \mathrm{I}_{\mathrm{i}}=\frac{\mathrm{I}_{\mathrm{i}}^{\text {end }}-\mathrm{I}_{\mathrm{i}}^{\text {beg }}}{\left(\mathrm{I}_{\mathrm{i}}^{\text {end }}+\mathrm{I}_{\mathrm{i}}^{\text {beg }}\right) / 2}
$$

$\mathrm{I}_{\mathrm{m}}^{\mathrm{n}} \mathrm{g}$ - particular assets or liabilities at the beginning and at the end of the reporting period.

The model extended by such independent variables as administration costs, sales costs, financial costs, indebtedness to the budget, and income tax liability - by using delta approach - introduced a significant decrease of the adjusted R-square (to the 0.194). From all determinants, the statistically significant were 'current liabilities for goods, work and services' (Beta coefficient $=0.482$, 
$p-$ value $=0.01)$ and 'financial costs' (Beta coefficient $=0.481, p-$ value $=0.003)$. The variance inflation factor (VIF) remained at the level of 1 to 2 , showing the absence of multicollinearity. This result confirmed our first hypothesis because the influence of current liabilities for goods, work, and services on retained earnings remained at the same level as the influence of financial costs.

\section{Logistic regression approach}

Considering a distorted presentation of the real situation in financial reports, we used logistic regression in the analysis of other hypotheses. First, we used traditional and manipulative tools in the model following the variable 'retained earnings.' The result ' 0 ' introduced a negative weak position over two years - in practice, a loss-making activity over two years is often used in bankruptcy prediction methodologies - while '1' meant a positive and relatively strong position in the same period.

According to the study, such a general model - with both traditional and manipulative tools as independent logistic variables - worked by supporting our hypothesis: Cox \& Snell $R^{2}=0.375$; Nagelkerke $R^{2}=0.507$. The most interesting coefficient was the overall percentage of correct predictions $-74 \%$ - which indicated the correctness of the model itself $(88.9 \%$ for the value ' 0 ' and $51.4 \%$ for the value ' 1 ').

Secondly, by choosing independent variables reflecting a strategy based on manipulative tools, it was obvious that the coverage of our model will be highly reduced, but it remained significant (Cox\&Snell $R^{2}=0.196$; Nagelkerke $\left.R^{2}=0.264\right)$, while the overall percentage of correct prediction was $69.2 \%$ ( $97 \%$ for ' 0 'and $37.8 \%$ for ' 1 ').

Thirdly, the result was to be similar (Cox\&Snell $R^{2}=0.187$; Nagelkerke $R^{2}=0.253$ ) in the case of independent variables reflecting a strategy based only on traditional tools in the model, while the overall percentage of correct prediction was $65.6 \%$ ( $91.1 \%$ for ' 0 'and $27 \%$ for ' 1 ').

\section{Nash equilibrium}

We assumed that the market involves two groups of 'players:' traditionalists and manipulators. The former group covered firms on the market that reflects profitability, while the latter comprised firms with a negative weak position during at least two years. Manipulative strategy was applied by a 'player' if $s /$ he used such tools as advance payments or accumulated debt from the suppliers of goods and services, the state, or the employees. Traditional strategy meant the use of the following tools: the differentiation of inventory costing methods, the method of amortization/depreciation, financial/operating lease, and the reduction of expenses. If we assumed that profitability is the desirable result, the choice between two strategies of using manipulative/traditional tools allowed us to determine the acceptability of a particular market model (traditional/manipulative/mixed) to describe the current situation and the effectiveness of selected models to achieve equilibrium. Consequently, Tables 4 and 5 introduced a payoff matrix based on the obtained results of logistic regressions - based on the overall percentage of correct predictions - concerning the influence of traditional and manipulative tools in doing business. Table 4 showed that firms would like to reach a desirable level of profitability, while Table 5 introduced the Nash equilibrium in the case of unprofitability.

We built a payoff matrix in the following way. The 'players' (traditionalists/manipulators) had to choose a target market according to the character of doing business. If 'players' selected the strategy of using manipulative tools, the validity of our model becomes the following: $97 \%$ - manipulative strategy led to loss (' 0 ' - is the value of the logistic variable); $37.8 \%$ - traditional strategy led to profitability (' 1 'is the value of the logistic variable in this case). Assuming that the retail industry operates only with manipulative tools, then the 'player'(the manipulator) who used manipulative strategy would operate at a loss - with the overall percentage of correct prediction being $97 \%$ - while able to reach profitability only with the overall percentage of correct prediction: $3 \%$. If the 'player' (the traditionalist) selected the traditional strategy of doing business - by using different approaches in inventory accounting, depreciation, just in time', etc. - and did not use manipulative tools in this market, s/he would reach profitability with the overall percentage of correct prediction: $37.8 \%$. Since this model introduced the case of seeking profitability, we formed a couple of [3\%; $37.8 \%]$ in the cell of the table. We filled the other cells in similar 
manner. Thus, in the case of seeking desired profitability, the Nash equilibrium in the Ukrainian market (Table 4) combined manipulative and traditional instruments [11.1\%; 51.4\%].

Table 4. Nash equilibrium in the case of searching profitability based on a selected sample: the total of 123 data lines of Ukrainian small enterprises in 2015-2018

\begin{tabular}{|l|l|c|c|c|c|}
\hline \multicolumn{2}{|c|}{$\begin{array}{c}\text { Part of market working in accordance with } \\
\text { (i.e. competitors): }\end{array}$} & \multicolumn{3}{c|}{ Traditionalist (traditional way of doing business) } \\
\cline { 2 - 6 } & Manipulative principles & \multicolumn{2}{c|}{ Traditional principles } \\
\hline $\begin{array}{l}\text { Manipulator (manipulative } \\
\text { way of doing business) }\end{array}$ & Manipulative principles & $3 \%$ & $\mathbf{3 7 . 8 \%}$ & $\mathbf{5 1 . 4 \%}$ & $11.1 \%$ \\
\cline { 2 - 6 } & Traditional principles & $\mathbf{1 1 . 1 \%}$ & $\mathbf{5 1 . 4 \%}$ & $\mathbf{8 . 9 \%}$ & $\mathbf{2 7 \%}$ \\
\hline
\end{tabular}

Source: own elaboration based on the results obtained from the regressions above.

Therefore, in the case of cell (traditional principles, manipulative principles), $100 \%-88.9 \%=$ $11.1 \%$. Since the goal was profitability, the hypothesis was not fulfilled. The percentage of correct predictions (51.4\%) remained unchanged according to the results of logistic regression. When we rejected at least one of the tools, the hypothesis in the mixed market with both types of instruments did not fully work. In the case of cell (traditional principles, traditional principles): $100 \%-91.1 \%=8.9 \%$ and $27 \%$, the percentage of correct predictions also remained unchanged.

Then, the manipulator selected e.g. a part of the market in which generally all firms work in accordance with manipulative principles, while the traditionalist chose the one in which all firms work in accordance with traditional principles. If they interacted within one common market, we received a situation of the upper right corner of the payoff matrix $(51.4 \% ; 11.1 \%)$. In this case, competitors obviously differed in their business strategies. In the case of the same principles of doing business, we received the situation of the upper left $(3 \% ; 37.8 \%)$ or lower right corners $(8.9 \% ; 27 \%)$.

Taking into account the possibility of changing the roles of manipulator and traditionalist - in the case of considerable political turmoil - the equilibrium could be obtained in only one cell out of two. This referred to the situation when e.g. a political force to which they remained loyal won the election, which led to the reduction of inspections, selective commitment to customs control, etc. In the economy where market institutions operate only in part, and the level of profitability reflects a 'healthy' business, market equilibrium appears by the use of strategies based partly on manipulative and traditional tools.

The other case we wanted to analyse, was the situation when unprofitability was not a problem (Table 5), while the institutional environment based on traditional principles along with the possibility of the hidden use of some manipulative principles (e.g. a failed procedure of bankruptcy). The Nash equilibrium in this case was received in the position of using traditional tools $(91.1 \%-$ for ' 0 '; $27 \%$ - for ' ${ }^{\prime}$ '), hence in the cell (91.1\%; 73\%).

Table 5. Nash equilibrium in the case of unprofitability based on selected sample: the total of 123 data lines of Ukrainian small enterprises in 2015-2018

\begin{tabular}{|l|l|c|c|c|c|}
\hline \multicolumn{2}{|c|}{$\begin{array}{c}\text { Part of market working in accordance with } \\
\text { (i.e. competitors): }\end{array}$} & \multicolumn{3}{c|}{ Traditionalist (traditional way of doing business) } \\
\cline { 2 - 6 } & Manipulative principles & \multicolumn{2}{c|}{ Traditional principles } \\
\hline \multirow{2}{*}{$\begin{array}{l}\text { Manipulator (manipulative way } \\
\text { of doing business) }\end{array}$} & Manipulative principles & $\mathbf{9 7 \%}$ & $62.2 \%$ & $48.6 \%$ & $\mathbf{8 8 . 9 \%}$ \\
\cline { 2 - 6 } & Traditional principles & $88.9 \%$ & $48.6 \%$ & $\mathbf{9 1 . 1 \%}$ & $\mathbf{7 3 \%}$ \\
\hline
\end{tabular}

Source: own elaboration based on the results obtained from the regressions above.

The same approach was used for other cells. Consequently, under such conditions, a firm working in accordance with the manipulative strategy (manipulator) calmly competed with firms using traditional business strategies, and their interaction was in equilibrium due to the inefficiency of market institutions.

Therefore, cannot fully confirm the second hypothesis of our study, but we can confirm the third one because the manipulator in the described situation was only able to reach equilibrium in the market with traditional tools. The second hypothesis is not proved probably because foreign capital works - though in insignificant volume - in the Ukrainian market and traditional accounting approaches were strictly regulated by foreign parent companies. Therefore, two types of strategies can be easily identified. In the case of unprofitability, we observed that the use of traditional accounting 
technologies allowed businesses to be in equilibrium. Therefore, the use of manipulative instruments does not ensure any additional 'advantage.' In this case, as we assumed, traditional tools were used by both firms that prefer manipulative tools and those forced to use traditional ones. Under such conditions, corporate income taxation becomes a fiction, while corporate tax revenue was simply negligible. For such a market, even a deeper approximation of national and international accounting standards would not lead to the increase of tax collection.

Therefore, without fundamental changes in the institutional environment, the incentive to abandon manipulative tools in doing business will not have a significant effect, as the business is in equilibrium partly by using this strategy (Table 4 ) that will create obvious resistance or not used at all (Table 5 ); e.g. changing the priorities of the banking system from the state bond market to the real business lending, the protection of property rights, the effective procedure of bankruptcy, the unification of tax and financial accounting, the illegality of all types of tax evasion.

\section{CONCLUSIONS}

Although this study is not the first attempt to conduct a comprehensive analysis of zombie businesses, it is one of the first attempts to apply this approach to a wide range of advanced manipulative tools of financial statements by applying game theory models. Considering the extremely dangerous influence of zombie business for the economy, our research focused on the problems of small enterprises in the Ukrainian market.

On the basis of the logistic regression approach, we found that if players are working on the market with only manipulative instruments, the validity of our model was $97 \%$ and manipulative strategy led to a loss; $37.8 \%$ - traditional strategy led to profitability. Meanwhile, if players are working on the market with only traditional instruments, the validity of our model was $91.1 \%$ and manipulative strategy led to a loss; $27 \%$ - traditional strategy led to profitability. Finally, if players are working on the market with traditional and manipulative instruments, then the validity of our model was $88.9 \%$ and manipulative strategy led to a loss; $51.4 \%$ and traditional strategy led to profitability.

Under the conditions of Ukrainian institutional environment our hypotheses are partly proved. We can state that such elements as the high level of informal institutions on the market, the simulation of bankruptcy procedures, the imperfections of audit practice, and stock market instruments led to extremely negative processes in domestic business. The lack of adequate sources of external investment forced businesses to deform their financial statements and seek investment funds in a completely inadequate way. Thus, our first hypothesis is completely confirmed.

The second hypothesis is not completely working because of the coexistence of foreign companies and domestic companies under adverse conditions in the market. The former are expected to consolidate their financial reporting with parent companies, while the latter can safely exist in a formal or informal market. Such a situation in the Ukrainian market creates a special type of zombie businesses created by ineffective government policy, in which a zombie bank - as a source of external financing - becomes an unnecessary link for such weak businesses. Solving such a problem is an extremely complex task and exceeds the horizon of the bank-enterprise relationship. On the other hand, such a situation in Ukraine results from the continued phenomenon of all-encompassing zombie banking sector.

In the case of unprofitability, the equilibrium among adherents of traditional principles and manipulative principles is reached in the market in which traditional strategies prevail. Under such conditions, even the use of manipulative principles loses its sense. The position of equilibrium is possible for the 'manipulator' only in the fully traditional market. But we do not see such a market in Ukraine. This explains why there are so many additional rules in Ukraine regarding what may be qualified as costs. There is no confidence in the market in terms of profitability or loss. If the market is in equilibrium in which players apply their strategies, the reforming, prohibition, or transformation of such a market will cause obvious resistance. If the accounting system does not have appropriate working mechanisms, there is no sense in taking care of the quality of standards. This is another reason for the approval of the third hypothesis. 
Therefore, our study reveals the essence of zombie business in Ukraine and informs about its risks and economic effects. We emphasize the undeniable fact that small business is totally unprofitable when run officially. We show the main business strategies used in business activity (manipulative and traditional). However, our study has its limitations as it could be the basis for a deeper analysis of business environment in Ukraine and ways for its improvement. Future research may also include a comparison of zombie businesses among different states. Thus, we recommend focusing on solving the challenges related to weak institutional environment and public policies.

\section{REFERENCES}

Acharya, V.V., \& Steffen, S. (2014). Falling short of expectations? Stress-testing the European banking system (CEPS Policy Brief, 315). Retrieved from https://ssrn.com/abstract=2381911 on January 15, 2020.

Ahearne, A.G., \& Shinada, N. (2005). Zombie Firms and Economic Stagnation in Japan. International Economics and Economic Policy, 2(4), 363-381. https://doi.org/10.1007/s10368-005-0041-1

Alfaro, L., Asis, G., Chari, A., \& Panizza, U. (2017). Lessons Unlearned? Corporate Debt in Emerging Markets. Cambridge: Harvard University.

Banerjee, R., \& Hofmann, B. (2018). The rise of zombie firms: causes and consequences. BIS Quarterly Review, 67-78. Retrieved from https://www.bis.org/publ/qtrpdf/r_qt1809g.pdf on February 12, 2020.

Berger, A., \& Bouwman, C.H.S. (2013). How Does Capital Affect Bank Performance During Financial Crises?. Journal of Financial Economics, 109(1), 146-176. https://doi.org/10.1016/j.jfineco.2013.02.008

Bilan, Y., Vasylieva, T., Lyeonov, S., \& Tiutiunyk, I. (2019). Shadow Economy and its Impact on Demand at the Investment Market of the Country. Entrepreneurial Business and Economics Review, 7(2), 27-43. https://doi.org/10.15678/EBER.2019.070202

Bilotkach, V. (2006). A Tax Evasion - Bribery Game: Experimental Evidence from Ukraine. The European Journal of Comparative Economics, 3(1), 31-49. https://doi.org/10.2139/ssrn.807004

Bush, S. (2018). Zombie Banks and Bank Bailouts. Retrieved from https://owlcation.com/social-sciences/Do-Zombie-Banks-Really-Exist on February 27, 2020.

Caballero, R.J., Hoshi, T., \& Kashyap, A.K. (2008). Zombie Lending and Depressed Restructuring in Japan. American Economic Review, 98(5), 1943-77. https://doi.org/10.1257/aer.98.5.1943

Deari, F., Matsuk, Z., \& Lakshina, V. (2019). Leverage and Macroeconomic determinants: evidence from Ukraine. Studies in Business and Economics, 14(2), 5-19. https://doi.org/10.2478/sbe-2019-0021

Dorożyński, T., Dobrowolska, B., \& Kuna-Marszałek, A. (2020). Institutional Quality in Central and East European Countries and Its Impact on FDI Inflow. Entrepreneurial Business and Economics Review, 8(1), 91-110. https://doi.org/10.15678/EBER.2020.080105

Fukuda, S., \& Nakamura, J. (2010). Why Did 'Zombie'Firms Recover in Japan? (CARF Working Papers, 224). Retrieved from https://www.carf.e.u-tokyo.ac.jp/old/pdf/workingpaper/fseries/234.pdf on April 17, 2020.

Google Books Ngram Viewer. Retrieved from https://books.google.com/ngrams on January 8, 2020.

Goto, Y., \& Wilbur, S. (2019). Unfinished business: Zombie firms among SME in Japan's lost decades. Japan and the World Economy, 49. https://doi.org/10.1016/j.japwor.2018.09.007

Henselmann, K., Ditter, D., \& Lupp, P. (2016). The effects of the financial crisis on cooperative banks in EuropeA critical comparison (Working Papers in Accounting Valuation Auditing, 2016-1). Nürnberg: Friedrich-Alexander-Universität ErlangenNürnberg.

Kanaya, A., \& Woo, D. (2000). The Japanese banking crisis of the 1990s: sources and lessons for Japan. Journal of Financial Economics, 97(3), 398-417.

Kawai, M. (2005). Reform of the Japanese banking system. International Economics and European Policy, 2(4), 307-335. https://doi.org/10.1007/s10368-005-0039-8

Kyselova, T. (2015). The Role of State in Ukrainian Business: Violent Bespredel and Profitable Partner. Kyiv Mohyla Law \& Politics Journal, 1, 83-112. https://doi.org/10.18523/kmlpj52658.2015-1.83-112

Lacalle, D. (2017). The Rise of Zombie Companies - And Why It Matters. Retrieved from Misses Institute: https://mises.org/library/ on January 7, 2020. 
Männasoo, K., Maripuu, P., \& Hazak, A. (2017). Investments, Credit, and Corporate Financial Distress: Evidence from Central and Eastern Europe. Emerging Markets Finance and Trade, 54(3), 677-689. https://doi.org/10.1080/1540 496X.2017.1300092

McGowan, M.A., Andrews, D., \& Millot, V. (2017). The walking dead: zombie firms and productivity performance in OECD countries (OECD Working Papers, 1372). https://doi.org/10.1787/180d80ad-en

Molina, C.A. (2005). Are Firms Underleveraged? An Examination of the Effect of Leverage on Default Probabilities. The Journal of Finance, 60(3), 1427-1459.

Mora, M. (2017). Dealing with non-performing loans. European versus Czech Perspective. Financial Stability Seminar, 11th Edition, Bucharest.

Nakaso, H. (2001). The financial crisis in Japan during the 1990s: how the bank of Japan responded and lessons learn (BIS Papers, 6). Retrieved from https://www.bis.org/publ/bppdf/bispap06.htm on February 12, 2020.

Novita, S., Tjahjadi, B., \& Irwanto, A. (2018). Industry and Financial Crises in Fragile and Zombie Firms: Does Leverage Matter?. Journal of Business and Economics Review, 3(3), 51-58.

Olaniyi, T.A., Elelu, M.O., \& Abdulsalam, T.S. (2015). Impact of Capital Structure on Corporate Performance: A Pre and Post Crisis Evaluation of Selected Companies in US. International Journal of Accounting Research, 2(8), 1-20.

Osório de Barros, G., Bento Caires, F., \& Xarepe Pereira, D. (2017). Zombie Companies in Portugal - The nontradable sectors of Construction and Services (GEE Papers, 88). Retrieved from http://www.oecd.org/globalforum-productivity/library/GEE_PAPER_88.pdf on December 24, 2019.

Radivojevic, N., \& Jovovic, J. (2017). Examining of determinants of non-performing loans. Prague Economic Papers, 26(3), 300-316. https://doi.org/10.18267/j.pep.615

Schivardi, F., Sette, E., \& Tabellini, G. (2017). Credit misallocation during the European financial crisis (BIS Working Papers, 669). Retrieved from https://www.bis.org/publ/work669.pdf on April 18, 2020.

Schnabl, G. (2013). The macroeconomic policy challenges of balance sheet recession: lessons from Japan for European crisis (CESifo Working Paper, 4249). Retrieved from https://papers.ssrn.com/sol3/papers.cfm?abstract_id=2274638 on December 15, 2020.

Schoenmaker, D., \& Peek, T. (2014). The state of banking sector in Europe (OECD Working Papers, 1102). https://doi.org/10.1787/18151973

Smallbone, D., Welter, F., Voytovich, A., \& Egorov, I. (2010). Government and entrepreneurship in transition economies: the case of small firms in business services in Ukraine. The Service Industries Journal, 30(5), 655-670. https://doi.org/10.1080/02642060802253876

State Statistic Service of Ukraine. (2019). Retrieved from http://www.ukrstat.gov.ua/ on January 17, 2019.

Stock market infrastructure development agency of Ukraine, Data Base. (2019). Retrieved from https://smida.gov.ua/db/emitent on December 3, 2019.

Storz, M., Koetter, M., Setzer, R., \& Westphal, A. (2017). Do we want these two to tango? On zombie firms and stressed banks in Europe (ECB Working Paper Series, 2104). Retrieved from https://www.ecb.europa.eu/pub/pdf/scpwps/ecb.wp2104.en.pdf on January 4, 2020.

Tiffin, A. (2006). Ukraine: the cost of weak institutions (IMF Working Paper, WP/06/167). Retrieved from https://www.imf.org/external/pubs/ft/wp/2006/wp06167.pdf on May 10, 2020.

Urionabarrenetxea, S., Garcia-Merino, J.D., San-Jose, L., \& Retolaza, J.L. (2018). Living with Zombie Companies: Do We Know Where the Threat Lies?. European Management Journal, 36(3), 408-420. https://doi.org/10.1016/j.emj.2017.05.005

Willam, D. (2015). Zombie banks and forbearance lending: causes, effects, and policy measures. (dissertation). Cologne: Leipzig University.

World Bank Group (2019). Doing business 2020, Economy profile of Ukraine. Retrieved from https://www.doingbusiness.org/content/dam/doingBusiness/country/u/ukr aine/UKR.pdf on January 12, 2020.

World Bank, Data Catalog, Doing Business. Retrieved from https://datacatalog.worldbank.org/dataset/doingbusiness on December 28, 2019. 


\section{Authors}

The contribution share of authors is:

Pedro Pardal - 30\%, Ihor Hurnyak - 40\%, and Aleksandra Kordonska - 30\%.

\section{Pedro Pardal}

Assistant Professor at the Department of Accounting and Finance and a Vice-Dean of the School of Business Administration, Polytechnic Institute of Setúbal (Portugal). He received his PhD in accounting from ISCTE Business School (Lisbon, Portugal). His research interests include accounting, finance, business management, and financial markets. He authored numerous peer-reviewed publications and monograph chapters in the field of accounting and finance.

Correspondence to: Pedro Pardal, ESCE, Campus do IPS, Estefanilha, 2910-503, Setúbal, Portugal, e-mail: pedro.pardal@esce.ips.pt

ORCID (10) http://orcid.org/0000-0003-3187-3472

\section{Ihor Hurnyak}

Associate Professor at the Department of International Economic Analysis and Finance, Faculty of International Relations, Ivan Franko National University of Lviv (Ukraine). He received his PhD in economics from the Ukrainian Academy of Foreign Trade of the Ministry of Economy and European Integration of Ukraine. His research interests include institutional economy, accounting, business management, and game theory models. He is the author and co-author of conference proceedings and over 40 peer-reviewed publications.

Correspondence to: Ihor Hurnyak, Ivan Franko National University of Lviv, Faculty of International Relations, Sichovych Strilciv 19, 79000, Lviv, Ukraine, e-mail: ag.kpl.Iviv@gmail.com

ORCID (1) http://orcid.org/0000-0003-0926-2456

\section{Aleksandra Kordonska}

Lecturer in the Institute of Political Science, University of Warmia and Mazury in Olsztyn (Poland) with a PhD in economics. Her research interests include business analysis, institutional economy, international competitiveness, international economic analysis, structural transformation of the economy, international economic relations. She is the author and co-author of over 40 peer-reviewed publications and monograph chapters, but also the editor of over 40 collective international scientific publications in the field of economy and international relations.

Correspondence to: Aleksandra Kordonska, Liliowa st. 17/16, 11-041, Olsztyn, Poland, e-mail: alexandra.kordonska@gmail.com

ORCID (1) http://orcid.org/0000-0002-5316-9630

\section{Acknowledgements and Financial Disclosure}

We would like to thank the anonymous referees for their useful comments, which permitted to increase the value of this article and also the editorial team for welcoming our research paper.

\section{Conflict of Interest}

The authors declare that the research was conducted in the absence of any commercial or financial relationships that could be construed as a potential conflict of interest.

\section{Copyright and License}

This article is published under the terms of the Creative Commons

Attribution - NoDerivs (CC BY-ND 4.0) License

http://creativecommons.org/licenses/by-nd/4.0/ 
